\title{
Iron at the center of ferritin, metal/oxygen homeostasis and novel dietary strategies
}

\author{
X LIU ${ }^{1,2} \mathrm{~K}^{\text {HINTZE }}{ }^{1,2}$ B LONNERDAL ${ }^{1,3}$ and EC THEIL ${ }^{1,2}$
}

${ }^{1}$ Center for BioIron at CHORI, Children's Hospital Oakland Research Institute, Oakland, California, USA,

2 Department of Nutritional Sciences and Toxicology, University of California, Berkeley, CA, USA, and

${ }^{3}$ Deptment of Nutrition, University of California, Davis, CA, USA.

\begin{abstract}
Bioiron - central to respiration, photosynthesis and DNA synthesis and complicated by radical chemistry with oxygen - depends on ferritin, the super family of protein nanocages (maxi-ferritins in humans, animals, plants and bacteria, and mini-ferritins, also called DPS proteins, in bacteria) for iron and oxygen control. Regulation of ferritin synthesis, best studied in animals, uses DNA transcription and mRNA translation check points. Ferritin is a member of both the "oxidant stress response" gene family that includes thioredoxin reductase and quinine reductase, and a member of the iron responsive gene family that includes ferroportin and mt-aconitase ferritin DNA regulation responds preferentially to oxidant response inducers and ferritin mRNA to iron inducers; heme confers regulator synergy. Ferritin proteins manage iron and oxygen, with ferroxidase sites and iron + oxygen substrates to form mineral of both $\mathrm{Fe}$ and $\mathrm{O}$ atoms; maxi-ferritins contribute more to cellular iron metabolism and mini-ferritins to stress responses. Iron recovery from ferritin is controlled by gated protein pores, possibly contributing to iron absorption from ferritin, a significant dietary iron source. Ferritin gene regulation is a model for integrating DNA/mRNA controls, while ferritin protein function is central to molecular nutrition cellular metabolism at the crossroads of iron and oxygen in biology.
\end{abstract}

Beneficial effects of iron and oxygen for bioenergetics (respiration and photosynthesis) are dependent on effective transport of iron and oxygen and in the case of iron, concentrators to match cellular need to low iron solubility. Proteins that correct for products of iron/oxygen chemistry, which escape transporters and concentrators or which are side products of catalytic reactions such as occur with cytochrome p-450s, or cytochrome oxidase in mitochondrial metabolism, include peroxidases, superoxide dismutases, and reductases.

Ferritin is a concentrator protein at the center of iron and oxygen metabolism $(2,5$, $13,14,18,20)$. The protein is a nanocage of $\alpha$-helices, assembled from 12 or 24 subunits of 4- $\alpha$-helix bundles, that surrounds a solid iron containing thousands of $\mathrm{Fe}$ and $\mathrm{O}$ atoms per protein. In nature, ferritins have a range of mineral sizes or may be devoid of iron and filled with water/ buffer $(4,19,23,25)$. The diameter of the cavity that accommodates the ferritin mineral inside the ferritin protein cage is 5 $8 \mathrm{~nm}$ (Fig. 1). The functions of the ferritin protein can be grouped in the categories of iron entry into the protein (oxidation, coupling though an oxo bridge, translocation to the cavity, and mineralization) and iron exit or release (reduction, hydration, and chelation by a biological or synthetic chelator). Cells regulate the amounts of ferritin protein both during cell differentiation (DNA target) and in mature cells (mRNA or postsynthetic targets). The function of ferritin as a natural nutritional source of iron in legumes, indicated as long as thirty years ago, recently has been recognized more completely $(1,6,17,20)$. 


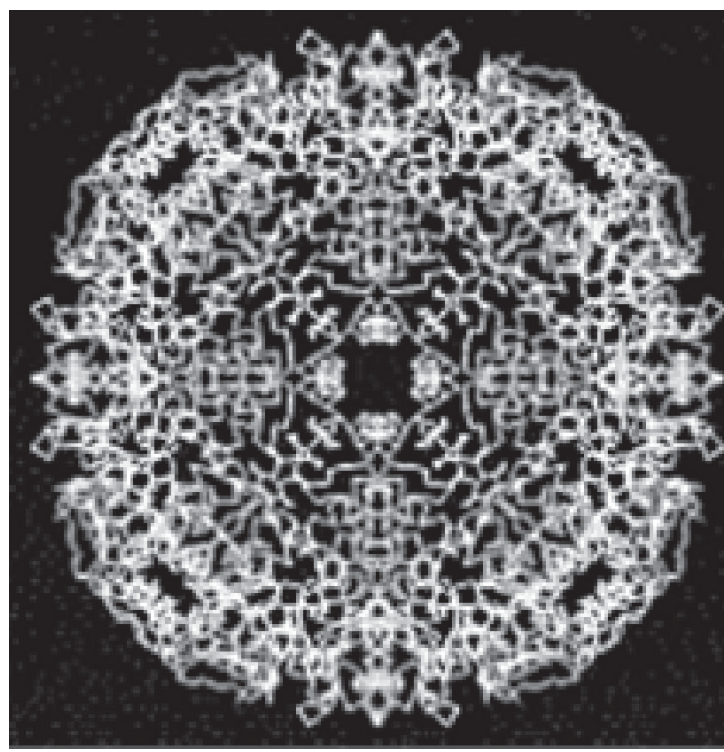

Figure 1. Structure of ferritin from protein crystals (PDB 1FR ) described in (26). Points in the carbon backbone of ferritin polypeptides were etched in lead crystal using a CADcontrolled, short laser beam developed by B. Grossman (www.bathsheba.com). Frog M ferritin, Pdb: 1MFR

\section{Regulation of ferritin synthesis}

Cellular iron and oxygen signals regulate the expression of ferritin (Fig. 2) at multiple sites. Transcription of ferritin DNA changes during differentiation and is very sensitive to oxidants and hemin, but only very high levels of non-heme iron have effects; all are targeted to an antioxidant response element or ARE, first discovered by the Torti group in the mouse $\mathrm{H}$ ferritin gene $(22,24)$. We recently have found an MRAE/ARE in the human L ferritin gene where hemin appears to coordinate regulation synergistically for the combined DNA element and the mRNA element (12). The only trans factors that have been identified to date are relatively generic and target a number of genes in addition to the ferritin.

Translation of ferritin mRNA has been studied much more extensively than transcription and has revealed a combinatorial family of mRNA noncoding structures that create a set of quantitative different, or hierarchal, responses withly two specific repressor proteins, sensitivity to both inorganic iron and oxygen signals, and interactions with one trans factor, eIF-4F (3, $7,10,11,16,21)$. In plants, animals and bacteria, the gene product of the ferritin family of genes - the protein nanocages is highly conserved. In contrast, subcellular location of ferritin is variable (organelles or cytoplasm or DNA-bound) $(2,5,13,14)$, the genetic regulatory targets and gene structure have diverged (18) (DNA or DNA + mRNA) and the regulatory signals can be $\mathrm{Fe}$, oxy derivatives, or both $(11,21)$ (Table 1) .

\section{Iron uptake in ferritin}

Among the many functions of ferritin the first in the series is protein-catalyzed, $\mathrm{Fe}$ oxidation reactions with $\mathrm{Fe}^{2+}$ and $\mathrm{O}_{2}$ to form diferric oxo mineral precursors. The catalytic coupling site is called the ferroxidase site and is present in every subunit of plant and bacterial (24 subunit) maxi-ferritins. In contrast, in animals a second gene encodes a catalytically inactive subunit, called $\mathrm{L}$ in a historic nomenclatures in which the active subunit is called H. Ferritin in animals cells is a mixture of ferroxidase active and inactive subunits, where ferritin in each cell type is a specific, distinct mixture. Bacteria also have a 12 subunit ferritin, or mini-ferritin, historically called a dps (DNA protection during starvation) protein, that is synthesized in response to stress, such as the production of hydrogen peroxide by a host or when nutrients are depleted. Mini-ferritins share with maxi-ferritins the reactions of iron oxidation, oxygen and peroxide consumption and iron biomineralization (26), but the effect is to protect DNA, in some cases by forming long chains of the protein nanocages that DNA wraps around to make a "bacterial chromatin" (8).

Amino acids at the ferroxidase active site of maxi-ferritins that are required for the formation of the first detectable reaction intermediate between ferrous ion and dioxygen, the blue diferric peroxo complex, were recently identified using protein chimeras (14). The catalytic sites in maxiferritins, molecule are related to oxygenases with di-iron cofactor sites, except that in ferritin both $\mathrm{Fe}$ and $\mathrm{O}_{2}$ are the substrates 


\section{Ferritin Regulation and Subcellular Distribution}
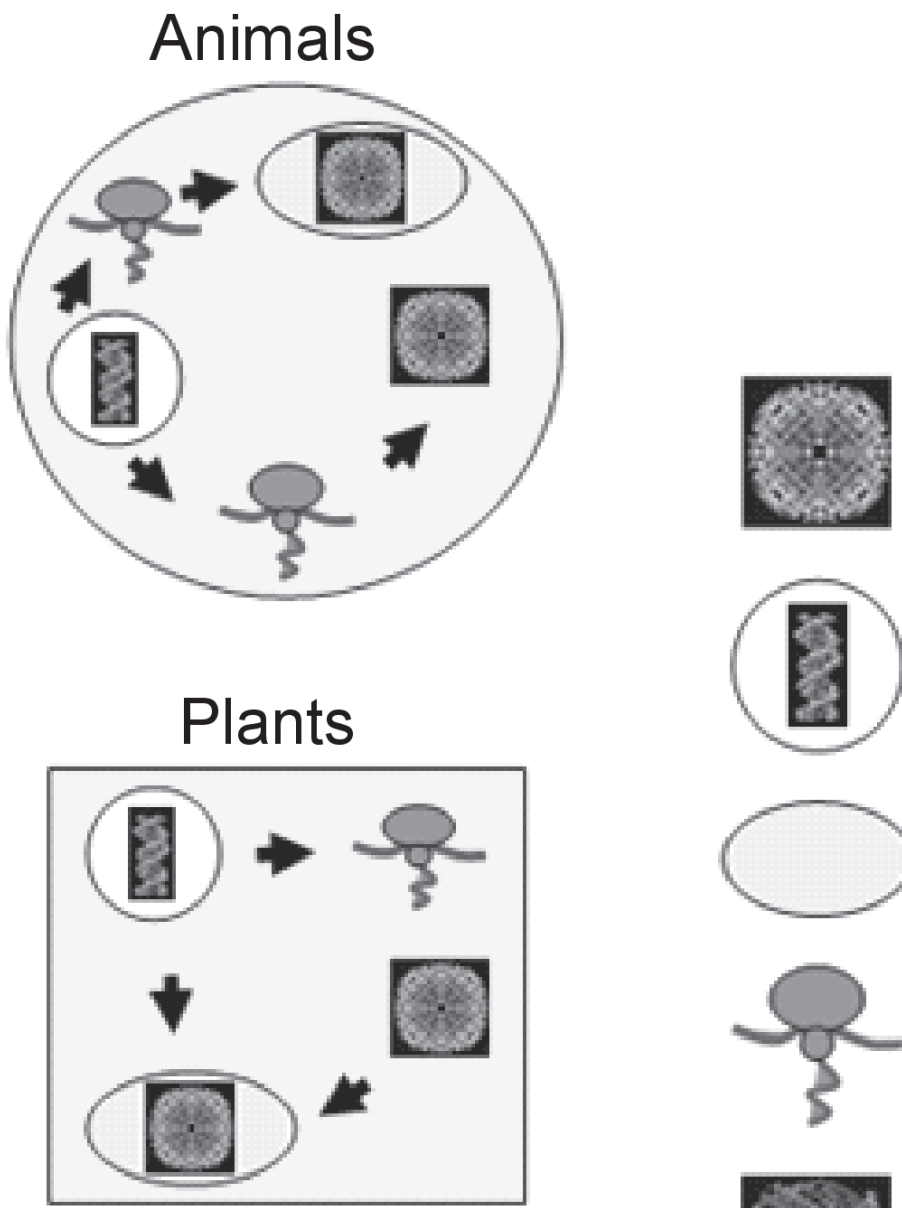

Ferritin protein

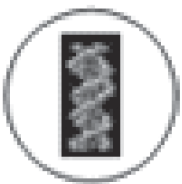

Nuclear DNA

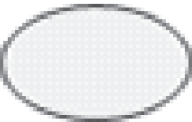

Mitochondrion /Chloroplast



Ribosome + Ferritin mRNA

+ Repressor (IRP)

Bacterial Ferritin ( Dps)
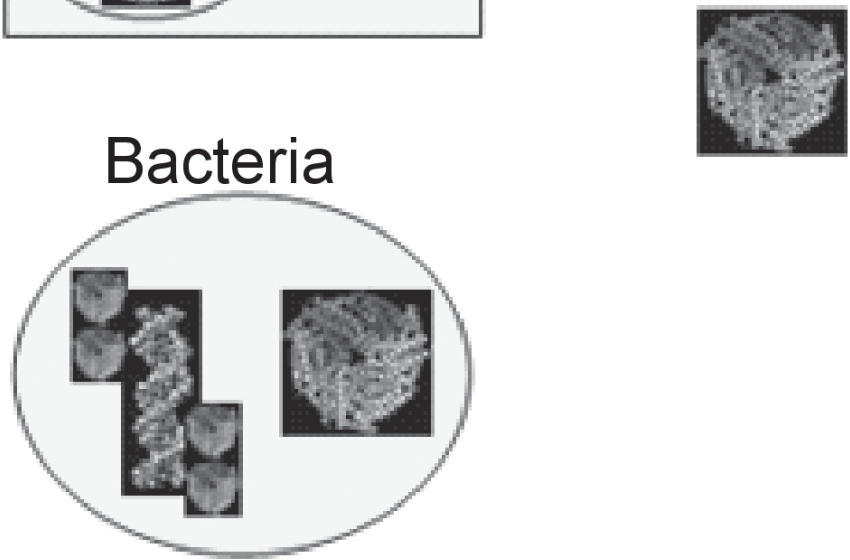

Figure 2. The different genetic regulatory mechanisms, signals and cellular location for the conserved ferritin family of protein nanocages with $\mathrm{FeO}$ minerals catalyzed by di-iron ferroxidase sites. Data are presented or reviewed in references 2, 5, 11, 18 and 21 and are tabulated in Table I. 
TABLE 1

Similarities and Differences Among the Ferritin Family: Conserved Protein Nanocages with Iron Minerals and Ferroxidase Activity

\begin{tabular}{llll}
\hline & Gene regulation & Signals & Cell Location* \\
\hline Animals & DNA, mRNA & $\mathrm{Fe}, \mathrm{O}_{2}$, & Cytoplasm, \\
& & $\mathrm{NO}, \mathrm{H}_{2} \mathrm{O}_{2}$ & Mitocdria \\
Plants & DNA & $\mathrm{Fe}, \mathrm{Fe}+\mathrm{Vit} \mathrm{C}$ & Plastid \\
Bacteria & DNA & $\begin{array}{l}\text { Stress, } \\
\text { Starvation }\end{array}$ & $\begin{array}{l}\text { Cytoplasm, } \\
\text { DNA bound }\end{array}$ \\
\hline
\end{tabular}

* All cells, varied with development/environment. The data are reviewed in references 2, 5, 11, 18 and 21 .

(21), in contrast to oxygenases where $\mathrm{O}_{2}$ and organic molecules are the substrates. Little direct information is available on the ferroxidase sites of mini-ferritins.

\section{Iron release from ferritin}

The sites for reduction and chelation of ferritin iron mineral $(8 /$ molecule) are related to other gated ion channels that unfold more readily $(1$ $\mathrm{mM}$ urea, temperatures of $56^{\circ} \mathrm{C}(15)$, compared to the rest of the molecule, which resists temperatures up to $80^{\circ} \mathrm{C}$ and $7 \mathrm{M}$ urea.

Nutritional availability of $\mathrm{Fe}$ has been demonstrated in humans from both purified ferritin or from whole soybeans, where most of the $\mathrm{Fe}$ is in ferritin $(2,18)$. The stability of ferritin protein to conditions of digestion, and the sequestration of seed ferritin inside the plastid membrane and the accumulation of ferritin in the hulls, indicate that food ferritin iron is absorbed, at least partly, at the enterocyte membrane surface. Understanding the mechanisms of absorption of iron from food ferritin and interactions with other food components are crucial to realizing the full potential of whole legumes as natural, sustainable dietary iron sources for battling global dietary iron deficiency (5).

\section{ACKNOWLEDGEMENTS}

Partial support from NIH - DK 20251, HL 56169 CHORI, and Cooley's Anemia Foundations.

\section{REFERENCES}

1. BEARD JL, BURTON, JOSEPH W, THEIL EC (1996) Ferritin and soybean meal can be sources of iron for treating iron deficiency in rats. J Nutr 126: 154-160

2. BRIAT JF, LOBREAUX S (1998) Iron storage and ferritin in plants. Met Ions Biol Syst 35: 563-584

3. CAIRO G, PIETRANGELO A (2000) Iron regulatory proteins in pathobiology. Biochemical Journal 352: 241-250

4. CHASTEEN ND, HARRISON PM (1999) Mineralization in ferritin: An efficient means of iron storage. J Struct Biol 126: 182-194

5. CHIANCONE E, CECI P, ILARI A, RIBACCHI F, STEFANINI S (2004) Iron and proteins for iron storage and detoxification. Biometals 17: 197-202

6. DÁVILA-HICKS P, THEIL EC, LONNERDAL B (2004) Iron in ferritin or in salts (ferrous sulfate) is equally bioavailable in nonanemic women. Am J Clin Nutr 80: 936-940

7. FILLEBEEN C, PANTOPOUlOS K (2002) Redox control of iron regulatory proteins. Redox Rep 7: 15-22

8. FRENKIEL-KRISPIN D, BEN-AVRAHAM I, ENGLANDER J, SHIMONI E, WOLF SG, MINSKY A (2004) Nucleoid restructuring in stationary-state bacteria. Mol Microbiol 51: 395-405

9. HA Y, SHI D, SMALL GW, THEIL EC, ALLEWELL NM (1999) Crystal structure of bullfrog M ferritin at 2.8 A resolution: Analysis of subunit interactions and the binuclear metal center. J Biol Inorg Chem 4: 243256

10. HANSON ES, RAWLINS ML, LEIBOLD EA (2003) Oxygen and iron regulation of iron regulatory protein 2. J Biol Chem 278: 40337-40342

11. HENTZE MW, MUCKENTHALER MU, ANDREWS NC (2004) Balancing acts: Molecular control of mammalian iron metabolism. Cell 117: 285-297

12. HINTZE KJ, THEIL EC (2005) DNA and mRNA elements with complementary responses to hemin, antioxidant inducers, and iron control ferritin-L expression. Proc Nat'l Sci 102: 15048-15052

13. LEVI S, CORSI B, BOSISIO M, INVERNIZZI R, VOLZ A, SANFORD D, AROSIO P, DRYSDALE J (2001) A human mitochondrial ferritin encoded by an intronless gene. J Biol Chem 276: 24437-24440

14. LIU X, THEIL EC (2004) Ferritin reactions: Direct identification of the site for the diferric peroxide reaction intermediate. Proc Nat'l Acad Sci USA 101 
15. LIU X, THEIL EC (2005) Ferritin: Dynamic management of biological iron and oxygen chemistry. Accounts of Chemical Research 38: 161-175

16. MEYRON-HOLTZ EG, GHOSH MC, ROUAULT TA (2004) Mammalian tissue oxygen levels modulate ironregulatory protein activities in vivo. Science 306: 2087-2090

17. MURRAY-KOLB LE, WELCH R, THEIL EC, BEARD JL (2003) Women with low iron stores absorb iron from soybeans. Am J Clin Nutr 77: 180-184

18. PROUDHON D, WEI J, BRIAT J, THEIL EC (1996) Ferritin gene organization: Differences between plants and animals suggest possible kingdom-specific selective constraints. Molecular Evolution 42: 325-336

19. THEIL EC (2001) Ferritin. In: MESSERSCHMIDT A, HUBER R, POULOS T, WIEGHARDT K (eds) Handbook of Metalloproteins. Chichester: John Wiley \& Sons. pp: 771-781

20. THEIL EC (2004) Iron, ferritin, and nutrition. Annu Rev Nutr 24: 327-343

21. THEIL EC, EISENSTEIN RS (2000) Combinatorial mRNA regulation: iron regulatory proteins and iso-iron responsive elements (iso-IREs). J Biol Chem 275: 40659-40662

22. TORTI FM, TORTI SV (2002) Regulation of ferritin genes and protein. Blood 99: 3505-3516

23. TRIKHA J, WALDO GS, LEWANDOWSKI FA, THEIL EC, WEBER PC, ALLEWELL NM (1994) Crystallization and structural analysis of bullfrog red cell L-subunit ferritins. Proteins 18: 107-118

24. TSUJI Y, TORTI SV, TORTI FM (1998) Activation of the ferritin $\mathrm{H}$ enhancer, FER-1, by the cooperative action of members of the AP1 and Sp1 transcription factor families. J Biol Chem 273: 2984-2992

25. YANG X, CHASTEEN ND (1996) Molecular diffusion into horse spleen ferritin: A nitroxide radical spin probe study. Biophys J 71: 1587-1595

26. ZHAO G, CECI P, ILARI A, GIANGIACOMO L, LAUE TM, CHIANCONE E, CHASTEEN N D(2002) Iron and hydrogen peroxide detoxification properties of DNA-binding protein from starved cells. A ferritin-like DNA-binding protein of Escherichia coli. J Biol Chem 277: $27689-27696$ 